\section{Drinking water and food security in hard rock areas of India}

\section{Edited by Subhajyoti Das}

Geological Society of India, Bangalore 2008, 263 p., Price: Rs.600

ISBN: 978-81-85867-87-8

This Golden Jubilee volume gives a useful and detailed discussion of the aspects of groundwater resources available, water, soil and crop management practices, and the roles of different stakeholders in integrated land and water management practices in hard rock areas of India. The memoir is an outcome of deliberations on the theme at a National Seminar held at Hulkoti, Karnataka, southern India, in April 2008. It publishes some of the basic scientific papers at the meeting elucidating the hydrogeology of different hard-rock areas and describes some of the successful land and water management practices and experiences of the different stakeholders in land, water and crop management.

The volume is introduced by Subhajyoti Das and his article entitled 'Water Management - Some Recent Studies and Experiences' highlights the fact that more than $60 \%$ of the cultivated area in India remains rain-fed and groundwater-dependent. He stresses that integrated management of surface water, groundwater and soil, coupled with the appropriate selection of crops, is the best way to combat water scarcity. The article elucidates some of the studies related to the combined use of surface water and groundwater, and the artificial recharge and rainwater harvesting currently conducted in India.

The section on groundwater resources and monitoring has papers giving insight into the hydrogeology of Karnataka and statistical tools used in groundwater management. Articles by Najeeb et al. and S. Murthy focus on the region's groundwater resources. An article by S. Ahmed discusses the optimization of groundwater monitoring network stations and suggests that by using geostatistical techniques the network of groundwater monitoring stations could be reduced without compromising the spatial range of the data.
The section 'Water, Soil and Crop Management' has nine papers, which give some good case studies related to efficient water, soil and crop management in some of the hard-rock areas of India that could be replicated in other parts of the country. The paper by G.K. Veeresh deals with the historical perspective of the use of droughtproofing technology in India for insuring agriculture against rainfall deficiencies. Shreedhara et al. elaborate on an action plan for the development of the Hirehalla Watershed in the Gadag district, Karnataka, using GIS and remote sensing. The article of Patil et al. focuses on land evaluation of the Bhanapur micro-watershed and the 48A distributary of the Malaprabha right bank command in Karnataka using GIS and remote sensing techniques. Dasog et al. emphasize the optimization of surface water and groundwater resources and the use of rainwater, tank water and borewell water to bring sustainable improvements in crop yields in tank command areas of North Karanataka. Ramappa et al. establish the efficiency of drip irrigation in relation to flood irrigation and demonstrate its advantages for water conservation, increased crop productivity, and energy conservation. Masagi et al. highlight the success story of an innovative water harvesting technique in the perspective of local geology adopted by Water Literacy Foundation in the Gadag district of Karnataka. Their paper is furnished with some beautiful illustrations. Rajarajan et al. present a case study of the Basavpura micro-watershed in Gauribidnaur Taluk, Kolar district, Karnataka, where, using GIS and remote sensing, areas suitable for artificial recharge structures have been identified and delineated. A paper by Venugopal examines the groundwater legislation proposed in the Model Bill circulated by the Indian Government's Ministry of Water Resources. It also highlights the proposed Karnataka Groundwater Bill leading to the establishment of the Groundwater Authority.

The section 'Water Quality and Drinking Water' has four papers. Prasad Raju presents the success story of the 'Safe Water for Everyone using Effective Technology' project of the Byrraju Foundation based on the Panchayat-Public-Private partnership model. R.P. Kulkarni presents the story of the Jal Nirmal Project, taken up in sixteen districts of Karnataka, which was aimed at achieving an equitable distribution of water and sustainability of water supply in rural areas. The paper focuses on the successful implementation of the project in the Gadag district of Karnataka. The paper by Gangadhrmurthy et al. is also a good case study from the Gadag district, giving an in-depth understanding of the factors controlling the occurrence of fluoride in the area and ways and means of diluting the fluoride content in water by recharge or runoff management. Gudagur et al. also give insights into the fluoride incidence in groundwater of parts of the Gadag district.

The section on 'Mass Mobilisation and Role of Financial Institutions in Water Management' has five papers. The paper by B. Patel emphasizes the collective action of society, with the participation of all stakeholders in the equitable distribution and efficient use of limited water resources through various approaches to rejuvenating water bodies, rainwater harvesting and groundwater regulation, in order to achieve both economic prosperity and social justice. S.V. Srikantia gives an account of the watershed development program in the Darewadi, Ralegaon Sidhi and Hiware Bajar watersheds, Ahmednagar district, Maharashtra, leading to the overall prosperity in the area. L.G. Hiregoudar et al. highlight the effort of K.H. Patil Krishi Vigyan Kendra in Gadag district in drought proofing and the socioeconomic resurgence achieved through biophysical and socioeconomic interventions. A. R. Khan highlights the status of irrigation potential, the involvement of banks in financing irrigation projects, the role of State and Central Governments and NABARD in creating the irrigation infrastructure in Gadag district and the new initiative for promoting artificial recharge and rainwater harvesting projects in an integrated manner. J.K. Jamadhar highlights the role of journalists in water literacy and mentions the work of some of the eminent leaders in the field of water management. The concluding remarks by Subhajyoti Das summarize the volume.

The volume is a useful compilation of papers and will provide valuable reference material for scientists and academics and planners, technocrats and bureaucrats.

\author{
Shashank Shekhar \\ Department of Geology \\ University of Delhi \\ Delhi - 110007 \\ Email:shashankshekhar01@gmail.com
}

